„Przekłady Literatur Słowiańskich”. T. 10, cz. 1

ISSN 2353-9763 (wersja elektroniczna)

DOI https://doi.org/10.31261/PLS.2020.10.01.12

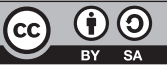

\title{
Herta Müller - pisarka z obrzeży w przekładzie na język czeski
}

\section{Herta Müller - An Author from the Periphery, Implications for the Translation into Czech}

\author{
Jakob Altmann \\ iD https://orcid.org/0000-0001-7547-6036 \\ UNIVERSITY OF SILESIA IN KATOWICE \\ kuba.alt@interia.pl
}

Data zgłoszenia: 3.09 .2019 r. | Data akceptacji: 18.02 .2020 r.

\begin{abstract}
This paper will be devoted to the peripheral nature of Herta Müller's oeuvre. Müller is regarded as a person who created "German-language literature from the cultural periphery of the German linguistic area." In relation to translation, the article aims to determine what place Czech translations of Müller's oeuvre occupy in Czech literature compared to German literature. The research also focuses on the issue of embedding translation in a polysystem that embraces translation as an interrelated system of culture, language, literature, and society.
\end{abstract}

KEYWORDS | polysystem, Czech translation, cultural periphery, Herta Müller 


\section{Sylwetka Herty Müller}

Motywacją do rozważań na temat wpływu peryferyjności dzieł Herty Müller na ich przekład jest stwierdzenie, że należą one do „literatury niemieckojęzycznej z kulturowych peryferii niemieckiego obszaru językowego" ${ }^{1}$. W związku z tym rodzi się pytanie, z jakich peryferii pochodzą dzieła niemieckiej autorki i czym one się charakteryzują.

Herta Müller urodziła się 17 sierpnia 1953 roku na terenie ówczesnej Rumuńskiej Republiki Ludowej, w miejscowości Nitzkydorf (rum. Niţchidorf) w rejonie Timişoary (Temeszwaru), w Banacie. Jest to region zamieszkany przez mniejszość niemiecką, zwaną Szwabami banackimi ${ }^{2}$. Miejsce to można nazwać "małą ojczyzną" (Heimatem ${ }^{3}$ ) Herty Müller. Użycie pojęć z dwu języków na określenie pochodzenia pisarki unaocznia ważne zagadnienie przekładoznawcze, Heimat stanowi bowiem w przekładzie na język polski „zerowy heteronim". Jest to termin stosowany przez Edwarda Balcerzana określający sytuacje, w których „słowo oryginału nie ma w języku przekładu swego heteronimu”4. O trudności przetłumaczenia wyrazu Heimat świadczy właśnie w języku polskim powszechnie stosowane wyrażenie mała ojczyzna, które jest używane z braku lepszych alternatyw. Ekwiwalencja między określeniami Heimat i mała ojczyzna obecna jest bowiem jedynie na poziomie funkcjonalności kulturowej, a rozwiązanie takie w przypadku słowa klucza nie jest pożądane ${ }^{5}$. Rozróżnienie między pojęciami Heimat i Vaterland okazuje się niemożliwe w języku polskim, gdyż zarówno w ojczyźnie, jak i w małej ojczyźnie obecny jest semem ojciec (a więc Vater). W niemieckiej nazwie Heimat rdzeniem słowa jest natomiast Heim, czyli „dom” w znaczeniu 'czyjeś mieszkanie, dom (pod względem po-

1 P. Bozzi, 2005: Der fremde Blick: zum Werk Herta Müllers. Würzburg, Königshausen \& Neumann, s. 15. Wszystkie przekłady pochodzą od autora artykułu, o ile nie podano inaczej.

2 Por. niem. Banater Schwaben. Z powodu możliwych negatywnych skojarzeń po polsku nazywani są również Niemcami banackimi.

3 Mała ojczyzna w odróżnieniu od ojczyzny (za Andrzejem Majerem) „eksponuje przywiązanie nie do państwa, czyli według Stanisława Ossowskiego do ojczyzny ideologicznej, ale do znacznie węższej, osobistej - tj. lokalnej przestrzeni i społeczności. $\mathrm{W}$ ujęciu metaforycznym [...] rozumiany bywa jako miejsce spędzania dzieciństwa i staje się synonimem bliskości, prywatności [...]", czyli eksponuje bardzo podobne cechy jak Heimat u Anny Wierzbickiej (por. A. Wierzbicka, 1999: Język - umyst kultura. Wybór prac. Warszawa, PWN, s. 452). Por. A. Majer, 2011: Miasto osobiste. "Acta Universitatis Lodziensis. Folia Sociologica”, nr 36, s. 20.

4 E. Tabakowska, 2001: Językoznawstwo kognitywne a poetyka przekładu. A. Pokojska, tłum. Kraków, Universitas, s. 45.

5 K. Hejwowski, 2007: Kognitywno-komunikacyjna teoria przekładu. Warszawa, PWN, s. 81 . 
czucia bezpieczeństwa, przyjemnej domowej atmosfery) ${ }^{6}$. Czeski odpowiednik domov wykazuje natomiast duże podobieństwo zarówno pod względem koncepcyjnym, jak i słowotwórczym do niemieckiego Heimat: formanty -ov i -at stanowią czynnik rozróżniający te słowa kolejno od di̊m i Heim, ponieważ nie zawierają w sobie elementu „poczucia”. O wysokiej produktywności użycia wyrazu domov świadczy choćby fakt, że pojawia się on w czeskim hymnie narodowym (Kde domov můj).

Niemiecka zdobywczyni Literackiej Nagrody Nobla dorastała na prowincji, gdzie cała wieś Nitzkydorf była dla niej totalitaryzmem w miniaturze („The first dictatorship I knew was the Banat-Swabian village"7). Totalitaryzm ten ukształtował ją na całe życie i wciąż kształtuje, wpłynął on i nadal wpływa na jej twórczość. Dyskomfort, jaki odczuwała Müller, mieszkając na banackiej prowincji, nazywa w swoim stylu: „niemiecką żabą”, mając na myśli ciągłą inwigilację ze strony „patriotów lokalnych”, etnocentryzm i presję opinii publicznej. Z tego powodu tematycznie jej utwory wychodzą zawsze od szczegółu (wieś/prowincja), a ogół istnieje tylko w domyśle (państwo komunistyczne) i jest reprezentowany przez konkretne osoby (np. funkcjonariusza Pjele w Herztier albo strażnika obozu Schischtwanjonow w Atemschaukel).

Również ojciec Herty Müller w istotny - negatywny - sposób współksztaltował osobowość autorki. Odczuwała ona wobec niego właściwie tylko awersję. Wynikało to po części z jego brutalnych zachowań i alkoholizmu, przede wszystkim jednak z tego, że podczas II wojny światowej brał udział w zabójstwach dokonywanych przez SS („oddział ochronny”, do którego zgłosił się dobrowolnie w wieku 17 lat).

\section{Polisystem}

Według Itamara Evena-Zohara, izraelskiego kulturoznawcy, literaturę można ująć w kontekście polisystemu - czyli jako „system wielokrotnie złożony, układ rozmaitych systemów przecinających się i częściowo nakładających na siebie, wykorzystujących jednocześnie różne opcje, a przy tym funkcjonujących jako jedna całość o określonej strukturze, której elementy są od siebie współzależne"8. Koncepcja literackiego polisystemu nie jest sama w sobie niczym nowym.

6 Duden [hasło]. Dostępne w Internecie: https://www.duden.de/rechtschreibung/Heim [dostęp: 15.08.2019].

7 B. Haines, L. Marven, 2013: Herta Müller. Oxford, Oxford University Press, s. 17.

8 I. Even-Zohar, 2007: Teoria polisystemów. K. Lukas, tłum. „Przestrzenie Teorii”, nr 7, s. 349. 
Opiera się ona na tej samej myśli co Weltliteratur (literatura światowa) Goethego, z tym że u Evena-Zohara otrzymuje ona nazwę „makropolisystemu literackiego". Najogólniej rzecz biorąc, Goethe wychodzi z założenia, że wszystkie literatury - najpierw w Europie, potem na całym świecie - tworzą całość i wymieniają się wytworami umysłu między sobą, przy czym za naturalne centrum tego systemu uważał on kulturę niemiecką ${ }^{9}$ nie uwzględniając przy tym faktu, że centra się zmieniają. Według Evena-Zohara „różnorodność w kulturze jest szczególnie "namacalna« w przypadkach, gdy dana społeczność jest dwu- lub wielojęzyczna" ${ }^{10}$. W takiej sytuacji kultura może też posiadać dwa lub więcej systemów literackich. Z tego wynika na przykład, że ,języka standardowego nie sposób rozpatrywać w oderwaniu od szerszego kontekstu, jakim są jego warianty niestandardowe” ${ }^{11}$. Dlatego też „przekładów literackich na dany język nie można oddzielić od literatury oryginalnej pisanej w tym języku"12.

Obowiązuje to w szczególny sposób w twórczości Herty Müller i w przekładach jej dzieł. Język, jakim posługuje się autorka w swoich utworach, nie może być bowiem postrzegany po prostu jako język niemiecki, gdyż w ten sposób byłby on oderwany od dialektu banackiego i języka rumuńskiego, które współtworzą jej idiolekt ${ }^{13}$. Gdy powstaje przekład, wchodzi on w polisystem literacki danej kultury, przy czym jej determinantami są takie elementy, jak historia, ustrój polityczny, religia czy światopogląd. Już sam wybór danego dzieła do tłumaczenia świadczy o charakterze tej kultury. Teksty wybierane są według ich zgodności z najnowszymi trendami i innowacyjną rolą, jaką mogą odegrać w literaturze docelowej ${ }^{14}$.

Zwłaszcza w przypadku literatur mniejszych, więc i peryferyjnych, przekład pełni ważną funkcję, stanowiąc pewnego rodzaju dowód możliwości języka narodowego oraz służąc jego doskonaleniu. Dotyczy to w największym stopniu tłumaczeń tzw. arcydzieł literatury światowej, które mają za zadanie zapełnić

9 Za: K. Lukas, 2009: Das Weltbild und die literarische Konvention als Übersetzungsdeterminanten: Adam Mickiewicz in deutschsprachigen Übertragungen. Berlin, Frank \& Timme GmbH, s. 24-25.

10 I. Even-Zohar, 2007: Teoria polisystemów..., s. 350.

11 Ibidem, s. 351.

12 Ibidem.

13 Idiolekt można określić jako indywidualną realizację systemu językowego lub ogół cech językowych odróżniających od siebie mówców danego języka. Por. E. Oksaar, 2010: Idiolekt als Grundlage der variationsorientierten Linguistik. „Sociolinguistica”, t. 14, cz. 1, s. 37.

14 I. Even-Zohar, 1990: The Position of Translated Literature Within the Literary Polysystem. „International Journal for Theory and Analysis of Literature and Communication", cz. 11, nr 1, s. 47. 
luki w literaturze rodzimej ${ }^{15}$. Należy w tym miejscu nadmienić, że pojęcie „literatury mniejsze" nie jest oczywiście terminem absolutnym, gdyż wielkość literatury zmienia się z czasem. W XVIII wieku dominowała na przykład literatura i kultura francuska, podczas gdy dziś taką rolę odgrywa literatura angielska. Wpływ na to mają sytuacja społeczna, uwarunkowania historyczne, a także język. Będąc dostępna dla większej grupy czytelników (również takich, dla których dany język nie jest ojczysty, ale na tyle znany, by czytać w nim literaturę), literatura pisana $w$ tym języku ma większe szanse na zajęcie pozycji centralnej $\mathrm{w}$ makropolisystemie literackim. W polisystemie literatury przyjmującej w przypadku literatur mniejszych twórczość przekładowa może więc przesunąć się z peryferii $\mathrm{w}$ kierunku centrum. W porównaniu $\mathrm{z}$ literaturami takimi, jak angielska, niemiecka czy francuska, literatura czeska na przykład "potrzebuje” więcej przekładów arcydzieł, w konsekwencji przekład zajmuje w niej bardziej centralną pozycję.

Jakie miejsce $\mathrm{w}$ literaturze niemieckiej zajmuje natomiast proza Herty Müller? Aby odpowiedzieć na to pytanie, należy określić, czym jest literatura niemiecka, co jest zadaniem niełatwym. Pośrednio jej istnienie zakłada jakieś bliżej określone narodowe centrum, gdzie jest ona bardziej lub mniej niemiecka. Paola Bozzi, włoska germanistka, apeluje w związku z tym o nieustanne przekraczanie granic i o to, by zagraniczna literatura niemieckojęzyczna nie była zagarniana przez kulturę dominującą (jaką jest kultura niemiecka usytuowana w Niemczech), a zmierzała raczej do włączenia jej do literatury niemieckiej, nie negując jej inności ani nie uogólniając jej ${ }^{16}$. P. Bozzi widzi więc literaturę niemiecką jako polisystem, w którym to, co „inne”, jest integralną częścią jej całości i nie jest związane z pojęciem narodu i państwa. „Inne” to w tym wypadku, jak zaznaczono na początku, „literatura niemieckojęzyczna $z$ kulturowych peryferii niemieckiego obszaru językowego"17. Jedną z takich literatur jest tzw. rumäniendeutsche Literatur („literatura rumuńskich Niemców”), nazywana "piątą literaturą," zaraz po literaturze RFN, NRD, Austrii i Szwajcarii, i obejmująca twórczość niemieckojęzyczną z trzech regionów: Banatu, Siedmiogrodu i Bukowiny południowej ${ }^{18}$. Sama Müller jednak zdecydowanie odrzuca przypisanie jej do grupy autorów tejże literatury. Jej mąż, autor Richard Wagner, również urodzony w Rumunii, opisuje twórczość swoją i niektórych swych towarzyszy,

15 M. Juvan, 2014: Literatura światowa a przekład. A. Muszyńska, tłum. „Przekłady Literatur Słowiańskich", t. 5, cz. 1, s. 36.

16 P. Bozzi, 2005: Der fremde Blick: zum Werk Herta Müllers..., s. 16.

17 Ibidem, s. 15.

18 O. García, 2014: In deutscher Sprache dichten. Eine Minderheit in der Minderheit: die antirumäniendeutsche Literatur. W: K. Thorpe et al., eds.: Hospitality and Hostility in the Multilingual Global Village. Stellenbosch, African Sun Media, s. 321. 
takich jak Herta Müller, nawet jako anti-rumäniendeutsche Literatur („antyliteratura rumuńskich Niemców”) ${ }^{19}$.

Awersja do określenia rumäniendeutsche Literatur ma przede wszystkim związek z nasilającymi się od lat 70. ubiegłego wieku represjami wobec niemieckich autorów tworzących i urodzonych w Rumunii. Po roku 1980 w Rumunii literatura niemieckojęzyczna $\mathrm{z}$ reguły nie mogła w całości ukazywać się legalnie, a jedynie ta jej część, która była uznana przez reżim komunistyczny. Dlatego „legalną” twórczość tworzyli głównie tradycyjni autorzy piszący w stylu sielankowej literatury heimatu ${ }^{20}$, z którymi twórców takich jak Herta Müller czy Richard Wagner łączyło jedynie miejsce urodzenia. Grupa autorów piszących w tym duchu, należących do tzw. Aktionsgruppe Banat, definiowała się jako pierwsze pokolenie urodzone w socjalizmie i nieobciążone burżuazyjną i faszystowską przeszłością $^{21}$. Od początku grupą tą rządził pewien antagonizm: z jednej strony językowo była związana z niemieckim obszarem kulturowym, z drugiej strony tematycznie - ze środowiskiem rumuńskim ${ }^{22}$. Autorzy do niej należący nie chcieli w swoich tekstach chwalić losów niemieckich Szwabów naddunajskich (Donauschwaben), tak jak czynili to poeci poprzednich pokoleń. Pragnęli zamiast tego tworzyć zupełnie inną literaturę, która byłaby także niemiecka, a przy tym nowoczesna, współczesna i zdolna do konkurowania z literaturą Zachodu. Stali się w ten sposób mniejszością w mniejszości. Powód, dla którego Herta Müller odniosła sukces i przesunęła się do centrum niemieckiego polisystemu literackiego, należy upatrywać w podejmowanej przez autorkę uniwersalnej tematyce w połączeniu z nowatorskim, poetyckim językiem. Według kulturoznawcy i literaturoznawcy Norberta Ottona Ekego wyjątkowość prozy Herty polega na „uroku egzotyki w opisywaniu obcego, zaginionego z (literackiego) horyzontu percepcji, świata niemieckiej mniejszości w Rumunii i fascynacji językiem poetyckim [... $]^{\text {23 }}$.

19 P. Bozzi, 2005: Der fremde Blick: zum Werk Herta Müllers..., s. 19.

20 O. García, 2014: In deutscher Sprache dichten..., s. 323.

21 Ibidem.

22 Ibidem.

23 N.O. Eke, 1991: Herta Müllers Werke im Spiegel der Kritik (1982-1990). W: Idem: Die Erfundene Wahrnehmung: Annäherung an Herta Müller. Paderborn, Igel Verlag Wissenschaft, s. 117. 


\section{Przekład dzieł Herty Müller na język czeski w czeskim polisystemie literackim}

W kontekście pozycji przekładów dzieł Herty Müller w czeskim polisystemie literackim istotne jest pytanie, jakie miejsce zajmują w nim przekłady z języka niemieckiego jako takie. Kwestię tę trzeba rozstrzygać przede wszystkim w perspektywie diachronicznej, co również zauważa I. Even-Zohar, wskazując na to, że nie należy postrzegać literatury przekładowej jako całości, lecz w obrębie tłumaczeń z jednego języka przede wszystkim diachronicznie, a patrząc na ogół tłumaczeń w większym stopniu synchronicznie ${ }^{24}$.

Przekłady z języka niemieckiego zawsze zajmowały ważne miejsce w literaturze czeskiej, jednak szczególne znaczenie miały one w czasie odrodzenia narodowego, zwłaszcza za sprawą działalności Josefa Jungmanna. W tamtym okresie literatura czeska była budowana poprzez przekłady obcojęzycznych tekstów. Kultura, język i literatura czeska znajdowały się wtedy bowiem w kryzysie tożsamościowym po niemal 100 latach panowania łaciny i języka niemieckiego. Strona językowa tekstu odgrywała więc dla Czechów rolę pierwszorzędną, a strona merytoryczna jedynie drugorzędną. Co ciekawe, użycie języka czeskiego uważane było wręcz za postawę patriotyczną, dlatego przekład tekstu na rodzimy język był odbierany bardzo pozytywnie, jako oznaka tego wszystkiego, co język czeski jest w stanie wyrazić ${ }^{25}$. Czeskiemu społeczeństwu przekłady z języka niemieckiego nie były jednak potrzebne do zrozumienia danego utworu, a stanowiły jedynie przejaw postawy patriotycznej i „kryterium ogłady kulturowej narodu w rywalizacji z innymi”26. Szczególnie wśród ludności miejskiej i ludzi wykształconych znajomość języka niemieckiego była wręcz oczywistością. Na przełomie stuleci XIX i XX, gdy w literaturze czeskiej ważną pozycję zaczynała zajmować moderna, kluczową rolę odgrywała literatura przekładowa, która została de facto włączona do struktury funkcji, norm i zasad pisania i odbioru literatury ${ }^{27}$. Powstanie w 1918 roku Republiki Czechosłowacji wzmocniło jeszcze pozycję literatury przekładowej w czeskim polisystemie literackim, gdyż wraz z uzyskaną niepodległością ukazywało się jeszcze więcej przekładów niż dotychczas, choć nie szło to w parze ze wzrostem ich jakości.

24 Por. I. Even-Zohar, 1990: The Position of Translated Literature Within the Literary Polysystem..., s. 49.

25 Por. J. Veselý, 2002: České překlady z německy psané literatury. W: M. Hrala, red.: Kapitoly $z$ dějin českého překladu. Praha, Karolinum, s. 125.

26 M. Juvan, 2014: Literatura światowa a przekład..., s. 36.

27 Por. J. Veselý, 2002: České překlady z německy psané literatury..., s. 145-146. 
Miejsce, jakie dany przekład zajmuje w polisystemie literackim, zależy również od osobowości i błyskotliwości osoby tłumacza. Na początku XX wieku tłumaczami byli jednak często zwykli znawcy języka, więc w wielu przypadkach o przekładach wchodzących do kanonu literackiego nie mogło być mowy. Im bardziej rozpoznawalny jest tłumacz, tym naturalniej konkretny przekład staje się częścią danego polisystemu. Rozpoznawalną w Czechach tłumaczką jest Radka Denemarková, autorka wszystkich (pięciu, z których ostatni ukazał się w 2019 roku) czeskich przekładów prozy Herty Müller, która za jeden z nich (Atemschaukel - Rozhoupaný dech) otrzymała w 2011 roku najważniejszą nagrodę literacką w Czechach - Magnesia Litera. Oprócz literatury oryginalnej nagroda ta jest co roku przyznawana również w zakresie literatury przekładowej, co dowodzi, że przekład uznaje się za część czeskiego polisystemu literackiego. Dzięki swej podwójnej działalności: pisarskiej i translatorskiej, R. Denemarková postrzegana jest przez pryzmat nie tylko swoich dzieł oryginalnych, lecz także przekładów, przynosząc tym drugim większą popularność i przesuwając je bliżej centrum czeskiego polisystemu literackiego. Istotne znaczenie ma tu również fakt, że działalność przekładowa jest w jej przypadku zajęciem dodatkowym, równie wymagającym, jak twórczość oryginalna.

Aby ustalić miejsce przekładów na język czeski prozy Herty Müller, najpierw należy zastanowić się, gdzie umieścić jej twórczość w niemieckim polisystemie literackim. Jest to o tyle trudne zadanie, że istnieje pewna sprzeczność między popularnością pisarki, która rozpoczęła się właściwie wraz z jej debiutem na niemieckiej scenie literackiej ${ }^{28}$, a unikatową, podejmowaną przez nią tematyką, czyli życiem w mniejszości narodowej, doświadczającej w szczególny sposób okrucieństw dyktatury komunistycznej. Z powodu swojej archaiczności wynikającej z pewnej izolacji język ogólny utracił kontakt ze swoją macierzą, również anti-rumäniendeutsche Literatur może zostać uznana za peryferyjną. Choć literatura Herty Müller jest także Heimatliteratur, to jednak w zupełnie innym sensie, bo zamiast opiewać swój Heimat, swoją ojczyznę, tworzy z niej antyidyllę (np. w Niederungen czy Herztier).

Bez względu na pozycję, jaką zajmuje dana literatura w oryginale, w przekładzie odgrywa zupełnie nową rolę, gdyż tematyka, styl, forma albo język tłumaczonego utworu mogą być archaiczne w stosunku do aktualnych trendów ${ }^{29}$. W czeskim polisystemie literackim, jak można zauważyć, kolejne przekłady powieści Herty Müller zaczęły pojawiać się stosunkowo późno, bo dopiero począwszy od roku 2010. Pokazuje to, że temat komunistycznej przeszłości,

28 P. Bozzi, 2005: Der fremde Blick: zum Werk Herta Müllers..., s. 15.

29 Por. I. Even-Zohar, 1990: The Position of Translated Literature Within the Literary Polysystem..., s. 49. 
choćby dotyczącej innego kraju, przez długi czas był w Czechach niewygodny. Rozliczanie się z tym okresem czeskiej historii w pełni mogło się dokonać dopiero długo po aksamitnej rewolucji ${ }^{30}$. Wcześniej wartościowe pod względem jakości utwory poruszające kwestie niewygodnej przeszłości były publikowane na emigracji ${ }^{31}$. Na przykład w roku 1970 wydano w Kanadzie powieść Řešení gama (Rozwiązanie gamma) autorstwa Jaroslava Brodskiego ${ }^{32}$. Jest to pamiętnik zawierający przeżycia $\mathrm{z}$ łagru, do którego J. Brodský trafił na 10 lat po tym, jak oskarżono go o tzw. antypaństwową działalność. Historia jest tu przedstawiona jako niszczycielka losów.

Po aksamitnej rewolucji pierwszym utworem rozliczającym się z trudną przeszłością w Czechach była powieść Michala Viewegha Báječná léta pod psa powstała $\mathrm{w}$ roku $1992^{33}$. Jest to historia 30-letniego autora opowiadającego o latach „normalizacji” z humorem. Pisarz unika w niej zarówno narracji pozytywnej (normalizacja jako okres rozkwitu), jak i negatywnej (normalizacja jako upadek moralny), gdyż są to lata dzieciństwa i autora, i jego bohatera. Z czasem tym M. Viewegh łączy więc także szczęśliwe chwile, a historycznie chodzi o okres po inwazji wojsk Układu Warszawskiego na Czechosłowację w roku 1968. W roku 1996 z kolei ukazała się monografia antropologa społecznego Ladislava Holego pt. Malý český člověk a skvělý český národ ${ }^{34}$, będąca krytycznym studium czeskiej mentalności, w której ocenie poddaje się przede wszystkim sprzeczność między autostereotypem Czechów jako osób „kulturalnych, głęboko demokratycznych i czystych" a tym, co w przekonaniu autora cechuje ich naprawdę, czyli „zawiść, konformizm, małostkowość i nietolerancja”. Badanym okresem są lata normalizacji, czyli te same co w przypadku powieści M. Viewegha.

Trudności związane z pojawianiem się przekładów dzieł niemieckiej autorki wynikają także z jej transkulturowości, a więc z przenikania się w jej utworach różnych kultur i języków, takich jak języki i kultury Rumunii, Rosji czy Banatu, oraz z tematycznego osadzenia tych tekstów poza Niemcami. Między innymi dlatego wszystkie przekłady na język czeski dzieł Herty Müller ukazały się po roku 2009, a więc po przyznaniu jej Literackiej Nagrody Nobla za powieść Atemschaukel. Stała się ona wówczas na tyle popularna, że czeskie wydawnictwa

30 Por. J. Lehár et al., red., 2008: Česká literatura od počátků k dnešku. Praha, Nakladatelství Lidové noviny, s. 933.

31 Por. J. Czaplińska, 2014: Přidaná hodnota exilu: úvahy o české exilové literaturę po roce 1968. Praha, Episteme Academia, s. 41.

32 J. Brodský, 1970: Řešení gama. Toronto [wydanie na emigracji].

33 M. Viewegh, 1992: Báječná léta pod psa. Praha, Československý spisovatel.

34 L. Holý, 2001: Malý český člověk a skvělý český národ. Z. Uherek, tłum. Praha, Sociologické nakladatelství (SLON). 
musiały odpowiednio zareagować. Doceniono sposób, w jaki autorka „łącząc z sobą poezję i prostotę, nakreśla świat wykorzenienia" 35 .

Kluczowa przy zaszeregowaniu powieści Herty Müller do czeskiego polisystemu literackiego jest właśnie tematyka uwikłania w specyficzne przeżycia psychiczne i estetyczne, tj. ciągły strach przed tajnymi służbami, donosami czy cenzurą (jak w powieści Herztier - Srdce bestie) i deportacja na prace przymusowe (jak w powieści Atemschaukel - Rozhoupaný dech). Są to zjawiska, które wydają się wręcz bliższe czytelnikowi czeskiemu niż zachodnioniemieckiemu. Z kolei czytelnik wschodnioniemiecki mógł poznać w takim samym, jeśli nie większym stopniu, inwigilację systemu politycznego. $\mathrm{O}$ archaiczności tematyki nie może więc być mowy.

Trudności związane z przyjmowaniem przekładów powieści Herty Müller są jednak także natury estetycznej i psychologicznej. Estetycznej, bo „tłumacz faktycznie musi sobie wyobrazić, co tekst (autor tekstu) opisuje, czyli nie może poprzestać na etapie uchwycenia i zrozumienia znaczenia, na etapie semantyzacji”"36. Zgodnie z tą logiką, tłumacz, jedynie rozumiejąc i potrafiąc uchwycić znaczenie tytułu powieści Herztier, nie jest w stanie oddać ukrytej w nim ekspresji. Dodatkowym utrudnieniem jest tu fakt, że Herztier stanowi neologizm, a więc wyraz nieposiadający konkretnego skonwencjonalizowanego denotatu. Tłumacz musi więc przyjąć "postawę estetyczną"37, aby wyobrazić sobie „zwierzę” mające postać, kolor albo właściwości emocjonalne ewokowane przez „serce”. Również tylko w ten sposób może kojarzyć Herztier z warunkami panującymi w rumuńskim (i banackim) społeczeństwie z czasów komunistycznych.

Odpowiednią wrażliwością wykazała się dopiero tłumaczka Radka Denemarková, co pozwoliło jej między innymi na stworzenie wyrazu dwuczłonowego Srdce bestie, który doskonale odzwierciedla zarówno wartość poznawczą, jak i estetyczną oryginalnego Herztier. Jak sama przyznaje, czuje potrzebną każdemu tłumaczowi więź z autorem, a więc także z tekstami Herty Müller. Mając podobne poglądy i odczucia,

Zdecydowałam się, że to zrobię, choć wiem, że mnie czeka wiele zastrzeżeń, gdyż ja ten jej tekst słyszę. Ja go rozumiem, jestem do niego przywiązana. Tutaj wcale nie chodzi o pojedyncze słowa. Za tym stoi jakieś doświadczenie życiowe i każde

35 Oficjalna strona towarzystwa Nagrody Nobla, Literacka Nagroda Nobla 2009. Dostępne w Internecie: http://www.nobelprize.org/nobel_prizes/literature/laureates/2009/ press_ty.html [dostęp: 14.07.2019].

36 J. Kubaszczyk, 2013: Przekład dzieła literackiego jako konkretyzacja. „Scripta Neophilologica Posnaniensia", t. 13, s. 44.

37 Ibidem, s. 38. 
słowo ma wielką wagę. A ja obstaję przy swojej czeszczyźnie, którą jej [Hercie Müller - J.A.] podarowałam ${ }^{38}$.

Trudności natury psychologicznej są z kolei związane z ładunkiem emocjonalnym obecnym w twórczości Herty Müller. Jej utwory nasycone są bowiem wyłącznie emocjami negatywnymi, tj. strachem, beznadziejnością, przemocą i niemoralnością, co czeskiemu czytelnikowi może przypominać czasy komunistycznej dyktatury we własnym kraju, gdzie być może również on sam przyczyniał się do powstania i rozwoju kultury donosicielstwa oraz wszechobecności przemocy i niemoralności. Utwór językowo, tematycznie i emocjonalnie tak bezlitośnie rozliczający się z przeszłością komunistyczną mógł więc potencjalnie wywołać u czeskich odbiorców dyskomfort.

Jak współcześnie twórczość Herty Müller wpisuje się w czeski polisystem literacki pod względem artystycznym, tematycznym i stylistycznym, dobrze pokazuje przykład opublikowanej przed czterema laty książki Matěja Hořavy pt. Pálenka. Prózy z Banátu. Są to wspomnienia bezimiennego głównego bohatera i jednocześnie narratora, nauczyciela pracującego w rumuńskim wielokulturowym Banacie, gdzie w XIX wieku czescy emigranci założyli swoją osadę, podobnie jak Szwabowie banaccy w wieku poprzednim ${ }^{39}$. Akcja rozgrywa się w drugiej połowie ubiegłego wieku, pokazując zastój i beznadzieję tamtejszego świata. Jest to jeden z powodów, dla których główny bohater w swoich myślach często wraca do przeszłości spędzonej w Czechach i Bawarii. Jeden z recenzentów ująl przedstawione w książce środowisko w sposób następujący: „tamtejszy świat nie zna kategorii osiągnięć czy sukcesu, nie mówiąc o postępie. Jest to świat okrągły, który kurczy się przez to, jak wymiera” ${ }^{30}$. Charakterystyczna dla języka i stylu M. Hořavy jest mnogość dialektyzmów ( $\mathrm{z}$ „czeszczyzną banacką” na czele ${ }^{41}$ ) rozsianych po całym tekście i obecnych w ciągłych monologach,

38 Wywiad z Radką Denemarkovą przeprowadzony przez Milenę Štráfeldovą: Hertha Müller mi potvrdila, že je třeba jít do rizika, ř́ká její překladatelka Radka Denemarková. Dostępne w Internecie: http://www.radio.cz/cz/rubrika/udalosti/hertha-mueller -mi-potvrdila-ze-je-treba-jit-do-rizika-rika-jeji-prekladatelka-radka-denemarkova [dostęp: 1.07.2019].

39 Nie są to mimo wszystko jedyne narody, które w ciągu stuleci osiadły w Banacie. Należą do nich na przykład także Bułgarzy banaccy, którzy dotarli do tych terenów pod koniec XVII wieku.

40 P.A. Bílek, 2015: David Attenborough v rouše prozaickém. „Respekt.cz”. Dostępne w Internecie: https://www.respekt.cz/tydenik/2015/9/david-attenborough-v-rouse -prozaickem [dostęp: 7.07.2019].

41 M.S. Rakova, 2017: Asymetrie stylové př́znakovosti výrazových prostředků v českém a bulharském prékladu uměleckého textu. Dysertacja. Brno, Masarykova univerzita, Filozofická Fakulta, s. 116. 
a także fragmentaryczność, rytmiczność i poetyckość. Przypomina znaną z powieści Herty Müller szorstką poetyckość, wykorzystanie obrazowości języka rumuńskiego i dialektu banackiego, wprowadzenie neologizmów oraz fragmentaryczność. Raz mamy więc do czynienia z czeskim dialektem banackim, a raz $\mathrm{z}$ niemieckim dialektem banackim.

Te elementy dialektalne, tematyczne i stylistyczne obecne są między innymi w powieści Herztier, gdzie następują ciągłe zmiany perspektyw czasowych (raz narratorka wciela się w dziecko, raz w studentkę). Akcja nie postępuje chronologicznie, lecz autorka wprowadza fragmentarycznie kolejne wspomnienia. Używa przy tym języka, który dzięki nowatorskim połączeniom wyrazowym tworzy efekt niezwykłej poetyckości. Są to połączenia typu „plodit hřbitovy” („płodzić cmentarze”; w oryginale: „Friedhöfe machen”), których metaforyczność wynika z interakcji dwóch członów. Czasownik plodit może - podobnie jak niemieckie machen - tworzyć kolokację zarówno ze słowem hřbitov („cmentarz”), jak i dítě („dziecko”), o których mowa w dalszej części powieści ${ }^{42}$. Jedynie $\mathrm{w}$ ten sposób czytelnik sekundarny może, podobnie jak prymarny, dowiedzieć się, jak autorka gra opozycją śmierci („Friedhöfe machen”) i życia („[Kinder] machen” - „robić dzieci”). Podobny efekt szorstkiej poetyckości są w stanie wywołać również interferencje z języka rumuńskiego, na przykład neutralnie brzmiący rzeczownik „Kleinigkeiten” („drobiazgi”) występujący w znaczeniu „Eingeweide” („wnętrzności”).

\section{Zakończenie}

W jaki sposób i dzięki czemu pisarka z obrzeży funkcjonuje (czy nie funkcjonuje) w polisystemie literatury czeskiej, nienależącej do centrum polisystemu europejskiego? Okazuje się, że choć literatura czy antyliteratura rumuńskich Niemców znajduje się na kulturowych peryferiach niemieckiego obszaru językowego, twórczość Herty Müller zajmuje w literaturze niemieckiej pozycję centralną, głównie dzięki nieznanym dotąd niemieckiemu czytelnikowi obszarom tematycznym, ale również dzięki swojemu niezwykłemu językowi, będącemu konglomeratem idiolektu pisarki, pewnej archaiczności języka niemieckiego, dialektu banackiego oraz „słowoobrazów” (Wortbilder ${ }^{43}$ z z języka rumuńskie-

42 Por. H. Müllerová, 2010: Rozhoupaný dech. R. Denemarková, tłum. Praha, Mladá fronta, s. $21-37$.

43 J. Kubaszczyk, 2011: Wortbilder und Übersetzungsbilder. Eine Untersuchung zur Wortbildung als Bildbildung im Kontext der Übersetzungswissenschaft. Poznań, PWN. 
go. Uwarunkowania historyczno-polityczne, tematyka uwikłana w specyficzne przeżycia psychiczne i estetyczne obecne w jej utworach sprawiły, że przez długi okres (ponad 20 lat) nie powstał żaden przekład na język czeski. Jest to wszak także związane $\mathrm{z}$ artyzmem utworów Müller, pełnych niecodziennych metafor, neologizmów i wpływów z języków trzecich. Dlatego dopiero tłumaczka, której właściwym zajęciem jest pisarstwo oryginalne, mogła zająć się tak ambitną literaturą.

Współcześnie w literaturze czeskiej powstaje coraz więcej literatury zaangażowanej, rozliczającej się z komunistyczną przeszłością, o czym świadczą niedawno opublikowane opowiadania autorstwa Matěja Hořavy czy książki Petra Šabacha. Utwór M. Hořavy pokazuje także, że Niemców i Czechów łączy w dużym stopniu wspólna historia, nie tylko na terenie Czech i Niemiec, lecz także w tak odległym miejscu jak Banat. Ważne są również literackie zasługi w tym obszarze autorki należącej do młodszego pokolenia, Kateřiny Tučkovej, która w powieści Vyhnání Gerty Schnirch (w niedawno opublikowanym polskim przekładzie jako Wypędzenie Gerty Schnirch) omawia niewygodną dla Czechów kwestię wypędzenia Niemców po II wojnie światowej. Również sama Radka Denemarková w swoim debiucie literackim Peníze od Hitlera (Pieniądze od Hitlera) zajęła się tą tematyką. Pomimo upływu czasu (musiało minąć ponad 10 lat od aksamitnej rewolucji) pewne tematy były do niedawna nadal tabuizowane, jednak zaangażowanie niektórych autorów w ostatnich kilkunastu latach doprowadziło do znaczących zmian. Dzięki temu również przekłady prozy Herty Müller trafiają w Czechach na podatny grunt, na co decydujący wpływ ma tłumaczka, w wykonaniu której przekłady stają się sekundarnymi wytworami kultury, które wpisują się w czeski polisystem literacki. Ważnym czynnikiem wpływającym na pozycję literatury przekładowej w nim jest poza tym fakt, że język czeski należy do literatur mniejszych, w związku z czym twórczość z literatury większej - niemieckiej - łatwiej wchodzi w dialog z literaturą przyjmującą.

\section{Literatura}

Bílek P.A., 2015: David Attenborough v rouše prozaickém. „Respekt.cz”. Dostępne w Internecie: https://www.respekt.cz/tydenik/2015/9/david-attenborough-v -rouse-prozaickem [dostęp: 7.07.2019].

Bozzi P., 2005: Der fremde Blick: zum Werk Herta Müllers. Würzburg, Königshausen \& Neumann.

Brodský J., 1970: ̌̌ešení gama. Toronto [wydanie na emigracji]. 
Czaplińska J., 2014: Přidaná hodnota exilu: úvahy o české exilové literature po roce 1968. Praha, Episteme Academia.

Duden [hasło]. Dostępne w Internecie: https://www.duden.de/rechtschreibung/ Heim [dostęp: 15.08.2019].

Eke N.O., 1991: Herta Müllers Werke im Spiegel der Kritik (1982-1990). W: Idem: Die Erfundene Wahrnehmung: Annäherung an Herta Müller. Paderborn, Igel Verlag Wissenschaft.

Even-Zohar I., 1990: The Position of Translated Literature Within the Literary Polysystem. „International Journal for Theory and Analysis of Literature and Communication", t. 11, nr 1.

Even-Zohar I., 2007: Teoria polisystemów. K. Lukas, tłum. „Przestrzenie Teorii”, nr 7, s. 347-366.

García O., 2014: In deutscher Sprache dichten. Eine Minderheit in der Minderheit: die antirumäniendeutsche Literatur. W: K. Thorpe et al., eds.: Hospitality and Hostility in the Multilingual Global Village. Stellenbosch, African Sun Media. Haines B., Marven L., 2013: Herta Müller. Oxford, Oxford University Press.

Hejwowski K., 2007: Kognitywno-komunikacyjna teoria przekładu. Warszawa, PWN.

Holý L., 2001: Malý český člověk a skvělý český národ. Z. Uherek, tłum. Praha, Sociologické nakladatelství (SLON).

Hořava M., 2014: Pálenka. Prózy z Banátu. Brno, Host.

Juvan M., 2014: Literatura światowa a przekład. A. Muszyńska, tłum. „Przekłady Literatur Słowiańskich", t. 5, cz. 1, s. 20-37.

Kubaszczyk J., 2013: Przekład dzieła literackiego jako konkretyzacja. „Scripta Neophilologica Posnaniensia", t. 13, s. 37-54.

Kubaszczyk J., 2011: Wortbilder und Übersetzungsbilder. Eine Untersuchung zur Wortbildung als Bildbildung im Kontext der Übersetzungswissenschaft. Poznań, PWN.

Lehár J. et al., red., 2008: Česká literatura od počátků k dnešku. Praha, Nakladatelství Lidové noviny.

Lukas K., 2009: Das Weltbild und die literarische Konvention als Übersetzungsdeterminanten: Adam Mickiewicz in deutschsprachigen Übertragungen. Berlin, Frank \& Timme GmbH.

Majer A., 2011: Miasto osobiste. „Acta Universitatis Lodziensis. Folia Sociologica”, nr 36, s. 17-34.

Müller H., 2007: Herztier. Frankfurt am Main, Fischer Taschenbuch.

Müller H., 2009: Atemschaukel. München, Carl Hanser Verlag.

Müllerová H., 2010: Rozhoupaný dech. R. Denemarková, tłum. Praha, Mladá fronta.

Müllerová H., 2011: Srdce bestie. R. Denemarková, tłum. Praha, Mladá fronta. 
Nobelprize.org, [online]. Oficjalna strona towarzystwa Nagrody Nobla, Literacka Nagroda Nobla 2009. Dostępne w Internecie: http://www.nobelprize.org/ nobel_prizes/literature/laureates/2009/press_ty.html [dostęp: 14.07.2019].

Oksaar E., 2010: Idiolekt als Grundlage der variationsorientierten Linguistik. „Sociolinguistica", t. 14, cz. 1.

Rakova M.S., 2017: Asymetrie stylové príznakovosti výrazových prostředků v českém a bulharském překladu uměleckého textu. Dysertacja. Brno, Masarykova univerzita, Filozofická Fakulta.

Štráfeldová M., [online]: Hertha Müller mi potvrdila, že je třeba jít do rizika, říká její překladatelka Radka Denemarková. Dostępne w Internecie: http://www. radio.cz/cz/rubrika/udalosti/hertha-mueller-mi-potvrdila-ze-je-treba-jit-do -rizika-rika-jeji-prekladatelka-radka-denemarkova [dostęp: 1.07.2019].

Tabakowska E., 2001: Językoznawstwo kognitywne a poetyka przekładu. A. Pokojska, tłum. Kraków, Universitas.

Veselý J., 2002: České překlady z německy psané literatury. W: M. Hrala, red.: Kapitoly $z$ dějin českého překladu. Praha, Karolinum.

Viewegh M., 1992: Báječná léta pod psa. Praha, Československý spisovatel.

Wierzbicka A., 1999: Język - umyst - kultura. Wybór prac. Warszawa, PWN.

\section{Jakob Altmann}

\section{Herta Müller - An Author from the Periphery, Implications for the Translation into Czech}

SUMMARY | This paper entitled is devoted to the peripheral nature of Herta Müller's oeuvre. Müller is regarded as a person who created "German-language literature from the cultural periphery of the German linguistic area," as the Italian Germanist Paola Bozzi called it. It turns out that although the literature or anti-literature of the Germans of Romania is located on the cultural periphery of the German language area, Herta Müller occupies a central place in German literature, mainly due to subject areas unknown to West-German readers, but also due to her extraordinary language, which is a conglomerate of her idiolect, the archaic character of the German language used, the Banat-Swabian dialect and word-images from the Romanian language. The research, which is carried out from a mental, expressive, and cultural perspective, also focuses on the issue of embedding translation in a polysystem that embraces translation as an interrelated system of culture, language, literature, and society.

KEYWORDS | polysystem, Czech translation, cultural periphery, Herta Müller 


\section{Jakob Altmann}

\section{Herta Müllerová - autorka z periferie, implikace pro překlad do češtiny}

SHRNUTí | Tento př́spěvek s názvem „Herta Müllerová - autorka z periferie, implikace pro překlad do češtiny“ je věnován periferní povaze díla Herty Müllerové, která vyrostla a vytvořila „německou literaturu z kulturní periferie německojazyčné oblasti“, jak to uchopila italská germanistka Paola Bozzi. Ukazuje se, že ačkoli se literatura nebo antiliteratura rumunských Němců nachází na kulturní periferii německojazyčné oblasti, Herta Müllerová zaujímá ústř̌ední místo v německé literatuře, hlavně kvůli tématickým oblastem neznámým pro západoněmecké čtenáře, ale také kvưli svému výjimečnému jazyku, který je konglomerátem jejího idioleku, archaického charakteru její němčiny, banátsko-švábského dialektu a slovních obrázků z rumunského jazyka. Výzkum, který je proveden z mentálního, expresivního a kulturního hlediska, se zaměřuje také na otázku zabudování překladu do polysystému, který zahrnuje překlad jako vzájemně propojený systém kultury, jazyka, literatury a společnosti.

KLÍČOVÁ SLOVA | polysystém, český překlad, kulturní periferie, Herta Müller

JAKOB ALTMANN | dr w Instytucie Literaturoznawstwa Uniwersytetu Śląskiego w Katowicach. Absolwent bohemistyki i hispanistyki na Akademii Techniczno-Humanistycznej w Bielsku-Białej. Jako rodowity Niemiec bada niemiecką literaturę drugiej połowy XX wieku, ze szczególnym uwzględnieniem literatury niemieckiej noblistki Herty Müller oraz jej polskich i czeskich przekładów, z tego zakresu otrzymał grant w konkursie Preludium 15. Jego zainteresowania naukowe skupiają się na zagadnieniach językoznawczych widzianych w kontekście kulturowym. Jest autorem kilku artykułów obejmujących tematy przekładoznawcze i językoznawcze. Publikował m.in. w czasopismach „Przekłady Literatur Słowiańskich” i „Zora” oraz w jednym z tomów serii wydawniczej „Studia o Przekładzie”. Wygłosił referaty na kilku konferencjach krajowych i zagranicznych. 